\title{
SYNOPTIC AND MESOSCALE ANALYSIS OF EXTREME RAINFALL EVENT IN CILACAP METEOROLOGICAL STATION, INDONESIA ON DECEMBER 7, 2018
}

\author{
SUWIGNYO PRASETYO *, WAHYU KURNIAWAN, INLIM RAVIJAI RUMAHORBO \\ Departement of Meteorology, Indonesian State College of Meteorology \\ Climatology and Geophysics \\ Perhubungan I Street No. 5 Meteorology Cluster Area, Pondok Betung, Pondok Aren, \\ South Tangerang City, Banten, 15221, Telp. 021-73691621 \\ *email : prasetyosuwignyo8@gmail.com
}

\begin{abstract}
Abstrak. Curah hujan tertinggi selama lima tahun terakhir (2016-2020) tercatat sebesar 199,5 mm dalam dua puluh empat jam di Stasiun Meteorologi Cilacap. Penelitian ini mengkaji dinamika atmosfer dengan fokus pada skala sinoptik dan skala meso. Hal tersebut dilakukan karena curah hujan tinggi dengan durasi yang lama biasanya disebabkan oleh awan-awan yang tumbuh karena sirkulasi atmosfer skala yang lebih luas daripada hanya dipengaruhi oleh konveksi skala lokal. Seruakan massa udara dingin dari dataran tinggi Asia yang berpropagasi melintasi ekuator menjadi penyebab utama pada skala sinoptik. Selain itu, kecepatan angin yang cukup kuat dari arah selatan mendukung konvergensi dan memicu awan deep convective dengan meningkatkan adveksi udara hangat di Pulau Jawa bagian selatan, khususnya dalam hal ini daerah Cilacap. Analisis skala meso dilakukan menggunakan simulasi numerik untuk mengestimasi curah hujan secara spasial serta menggunakan citra satelit himawari-8. Simulasi numerik yang dilakukan menggunakan model Weather Research and Forecasting dengan penyesuaian skema parameterisasi tertentu belum mampu mengestimasi curah hujan dengan cukup baik dengan nilai yang underestimate dibandingkan dengan data observasi. Berdasarkan citra satelit himawari-8, terpantau dengan jelas bahwa awan yang terbentuk merupakan sistem awan konvektif skala meso dengan masa hidup lebih dari enam jam. Pertumbuhan awan tersebut cukup masif yang ditandai dengan nilai suhu puncak awan lebih rendah dari $-80^{\circ} \mathrm{C}$ pada fase matang. Dengan demikian, curah hujan yang dihasilkan termasuk hujan ekstrem sehingga mengakibatkan banjir di sebagian wilayah Cilacap.
\end{abstract}

Kata kunci: hujan ekstrem, analisis sinoptik dan skala meso, Stasiun Meteorologi Cilacap

Abstract. The highest rainfall for the last five years (2016-2020) was recorded at 199.5 $\mathrm{mm}$ in twenty-four hours at the Cilacap Meteorological Station. This study examines the dynamics of the atmosphere with a focus on the synoptic scale and the mesoscale analysis. This is done because high rainfall with a long duration is usually caused by clouds that grow due to wider-scale atmospheric circulation rather than only being influenced by local-scale convection. The outbreaks of cold air masses from the Asian highlands that propagates across the equator is the main cause on the synoptic scale. In addition, a fairly strong wind speed from the south supports convergence and triggers deep convective clouds by increasing the advection of warm air in the southern part of Java Island, especially in this case the Cilacap area. Meso-scale analysis was carried out using numerical simulations to estimate rainfall spatially and using Himawari-8 satellite imagery. Numerical simulations carried out using the Weather Research and Forecasting model with adjustments to certain parameterization schemes have not been able to estimate rainfall well enough with underestimated values compared to the observation data. Based on Himawari-8 satellite imagery, it is clearly observed that the cloud formed is a mesoscale convective cloud system with a life span of more than six hours. The cloud growth is quite massive, which is indicated by the cloud top temperature value is lower

JIIF (Jurnal Ilmu dan Inovasi Fisika), ISSN: 2549-0516 
than $-80^{\circ} \mathrm{C}$ in the mature phase. Thus, the resulting rainfall includes extreme rain, resulting in flooding in parts of Cilacap.

Keywords: extreme rainfall, synoptic and meso scale analysis, Cilacap Meteorological Station

\section{Pendahuluan}

Indonesia terletak di daerah tropis dimana kondisi cuaca dan iklim sangat dipengaruhi oleh sistem cuaca berbagai skala. Faktor pengendali cuaca dan iklim di Indonesia secara spasial terbagi menjadi beberapa skala. Pada skala atmosfer global, pengaruh dari kondisi perairan di Samudra Hindia dan Samudra Pasifik berdampak pada pembentukan cuaca di Indonesia. Daerah konvergensi dalam skala atmosfer global berasosiasi dengan aktivitas konvektif yang sangat tinggi. Hal tersebut berkaitan dengan terbentuknya sistem awan-awan konvektif penghasil hujan [1]. Variabilitas curah hujan antar tahunan di wilayah Indonesia dalam skala global dipengaruhi oleh ENSO (El Niño-Southern Oscillation) [2]-[7] dan IOD (Indian Ocean Dipole) [8]. Selain ENSO dan IOD, terdapat gangguan atmosfer skala global yang berpropagasi ke arah timur dengan periodisitas $30-60$ hari yang dikenal sebagai MJO (Madden Julian Oscillation) [9].

Pada skala sinoptik, variasi curah hujan di Indonesia dipengaruhi oleh aktivitas monsun [7]. Monsun merupakan pola sirkulasi angin yang berbalik arah secara periodik [10]. Selama monsun dingin Asia berlangsung, sering terjadi seruakan aliran udara dingin dari dataran tinggi Siberia yang disebut Cold Surge (CS). Aktivitas CS dapat menyebabkan peningkatan curah hujan di Laut Jawa, Kalimantan bagian barat dan wilayah Filipina bagian timur [11]. Selain itu, kondisi topografi Indonesia juga memainkan peran penting dalam pembentukan cuaca dimana efek kekasaran permukaan serta pemanasan matahari yang intens seringkali menimbulkan aliran turbulen di level rendah yang dapat membentuk awan-awan konvektif dalam skala yang lebih kecil.

Akhir-akhir ini, fenomena cuaca ekstrem menjadi perhatian serius terkait dengan isu perubahan iklim. Salah satu indikator terjadinya perubahan iklim adalah trend peningkatan suhu udara permukaan, yang mana ini telah terjadi di Pulau Jawa dalam 30 tahun terakhir (1990-2019) [12]. Selain itu, fenomena cuaca ekstrem seperti hujan ekstrem juga mengalami trend peningkatan untuk beberapa penelitian di sebagian wilayah Indonesia [13-14], terlebih lagi untuk wilayah pesisir [15]. Dalam hal ini, curah hujan tertinggi selama lima tahun terakhir (2016-2020) berdasarkan data laporan cuaca sinoptik terjadi pada tanggal 7 Desember 2018 di Stasiun Meteorologi Cilacap (SMC). Curah hujan tersebut tercatat dalam satu hari sebesar 199,5 mm. Nilai tersebut termasuk dalam kategori hujan ekstrem berdasarkan kategori yang dibuat oleh Badan Meteorologi Klimatologi dan Geofisika (BMKG).

Penelitian ini bertujuan untuk mengetahui bagaimana dinamika atmosfer skala sinoptik dan skala meso sehingga mendukung terjadinya hujan ekstrem di Cilacap. Fokus analisis dilakukan pada skala sinoptik dan skala meso karena hujan ekstrem dengan durasi yang lama seringkali disebabkan oleh awan-awan yang tumbuh karena sirkulasi atmosfer skala yang lebih luas daripada hanya dipengaruhi oleh konveksi skala lokal. Artikel ini tersusun dari Pendahuluan, Metode Penelitian, Hasil dan Pembahasan, serta Kesimpulan. 


\section{Metode Penelitian}

Data historis laporan berita sinoptik dari SMC diperoleh dari database BMKG dengan periode waktu lima tahun terakhir (2016-2020). Dari data tersebut kemudian difilter untuk menemukan akumulasi curah hujan tertinggi dalam satu hari. Dengan demikian, satu kasus diperoleh pada tanggal 7 desember 2018 dengan akumulasi curah hujan dalam satu hari sebesar 199,5 mm. Analisis dilakukan menjadi tiga tahapan yang akan dijelaskan pada paragraf berikut.

Pembahasan pertama kali dilakukan dengan melihat laporan berita dari laman online. Hal ini dilakukan untuk melihat dampak yang ditimbulkan dari hujan eksrem ini. Selanjutnya, analisis dilakukan berdasarkan peninjauan berbagai skala sirkulasi atmosfer. Peninjauan atmosfer skala global dilakukan untuk melihat pengaruh yang ditimbulkan oleh fenomena variabilitas iklim yang terjadi secara periodik. Analisis kemudian dilakukan secara mendalam pada skala sinoptik dan skala meso untuk melihat secara lebih detail penyebab terjadinya hujan ekstrem tersebut.

Data model reanalisis digunakan untuk menganalisis sirkulasi atmosfer pada skala sinoptik. Data tersebut diperoleh dari model reanalisis ERA5 dengan resolusi spasial $0.25^{\circ} \times 0.25^{\circ}$ dan resolusi temporal tiap enam jam [16]. Beberapa parameter yang dianalisis antara lain suhu potensial, relative humidity $(\mathrm{RH})$, dan angin lapisan $925 \mathrm{mb}$. Analisis pada skala meso dilakukan dengan menggunakan citra satelit himawari kanal inframerah [17]. Selain itu, simulasi numerik juga digunakan untuk mendapatkan estimasi curah hujan, convective available potential energy, dan komponen angin vertikal. Model set up dijelaskan pada paragraf berikut.

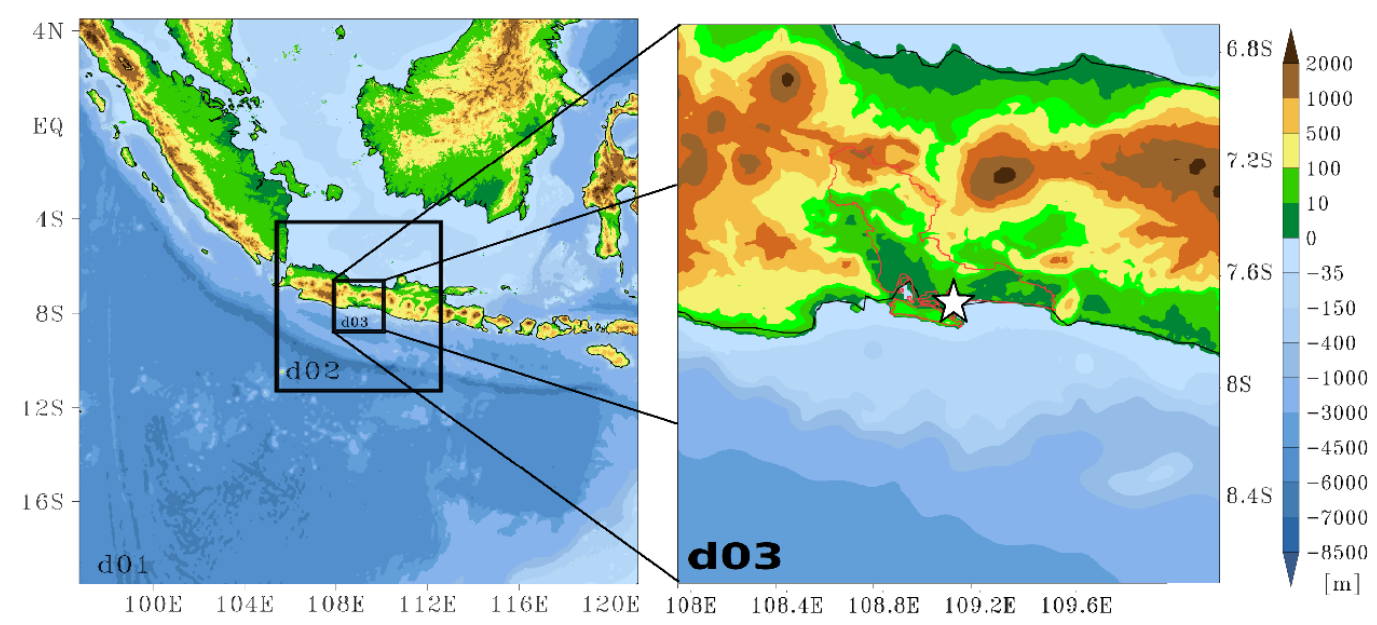

Gambar 1. Domain penelitian dengan tanda bintang pada gambar sebelah kanan merupakan pusat nesting model.

Simulasi numerik menggunakan data National Center for Environmental Prediction (NCEP) Final Analysis (FNL) dengan resolusi spasial $1^{\circ} \times 1^{\circ}$ serta resolusi temporal 6 jam sebagai data input model [18]. Model yang digunakan dalam penelitian ini menggunakan model Weather Research and ForecastingAdvance Research (WRF-ARW) versi 4.0 yang merupakan model simulasi untuk skala meso yang dikembangkan oleh National Center for Atmospheric Research 
(NCAR). Penelitian ini menerapkan tiga kali nesting domain dengan masingmasing domain sebesar 27, 9, dan $3 \mathrm{~km}$ seperti yang tertera pada Gambar 1. Titik tengah pada koordinat $7^{\circ} 38^{\prime} 54^{\prime \prime}$ LS dan $109^{\circ} 02^{\prime} 78^{\prime \prime}$ BT yang merepresentasikan Stamet Cilacap. Skema parameterisasi yang digunakan disesuaikan berdasarkan penelitian Wicaksono \& Kurniadi (2017) [19]. Penyesuaian dilakukan pada skema parameterisasi cumulus, microphyisics, dan planetary boundary layer masingmasing yaitu skema Kain-Fritsch (KF), Morrison 2-Moment (M2M), dan MellorYamada-Janjic (MYJ). Luaran data WRF kemudian dibandingkan dengan data observasi Automatic Weather Station (AWS) SMC dan data Global Satellite Mapping of Precipitation (GSMaP) untuk curah hujan secara spasial.

\section{Hasil dan Pembahasan}

\subsection{Dampak Hujan Ekstrem dan Faktor Skala Global}

Kejadian hujan ekstrem yang seringkali terjadi di berbagai wilayah indonesia dapat menimbulkan berbagai macam bencana. Curah hujan tinggi dengan durasi yang lama berpotensi menimbulkan genangan yang biasa disebut banjir. Hal ini sesuai dengan laporan [20] bahwa hujan sangat lebat dengan durasi yang lama pada tanggal 7 Desember mengakibatkan banjir di sejumlah titik di Kabupaten Cilacap (Gambar 2). Kejadian banjir ini terjadi akibat hujan sangat lebat dengan durasi yang lama selama beberapa hari, dimana pada tanggal 7 Desember banjir sudah mulai surut. Selain hujan sangat lebat dengan durasi yang lama, banjir di wilayah Cilacap seringkali dapat tejadi karena dipengaruhi oleh kondisi topografi wilayah.

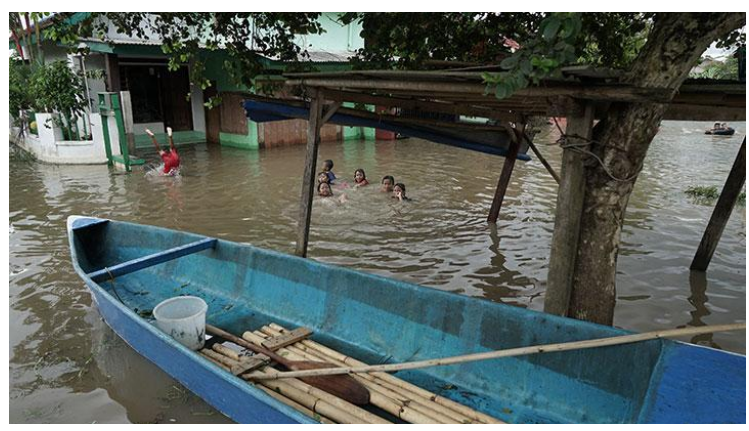

Gambar 2. Banjir yang terjadi di sebagian wilayah Cilacap pada 7 Desember 2018 [20].

Faktor atmosfer skala global dilakukan berdasarkan fenomena ENSO, IOD, dan MJO. Berdasarkan indeks Nino3.4 dan Dipole Mode Index (DMI) diperoleh dari NOAA (www.psl.noaa.gov/gcos_wgsp/) masing-masing bernilai +0.97 dan +0.38 pada bulan Desember yang menandakan bahwa sedang terjadi fenomena El Nino lemah dan IOD yang berada pada fase netral. Selain itu, data monitoring MJO yang diperoleh dari BoM (www.bom.gov.au/climate/mjo/) juga masih berada pada wilayah Samudera Hindia. Dengan demikian, ENSO, IOD, dan MJO tidak berpengaruh pada kejadian hujan ekstrem tanggal 7 Desember 2018.

\subsection{Analisis Skala Sinoptik}

Analsis skala sinoptik dilakukan dengan fokus bahasan pada profil angin lapisan $925 \mathrm{mb}$. Lapisan ini dipilih karena merepresentasikan kondisi atmosfer permukaan yang berhubungan langsung dengan dinamika cuaca dibawahnya namun telah 
bebas dari gangguan topografi permukaan. Komposit peta sinoptik ditampilkan pada Gambar 3, dimana profil angin di overlay dengan suhu potensial permukaan (shaded) dan relative humidity (RH) lapisan $700 \mathrm{mb}$.
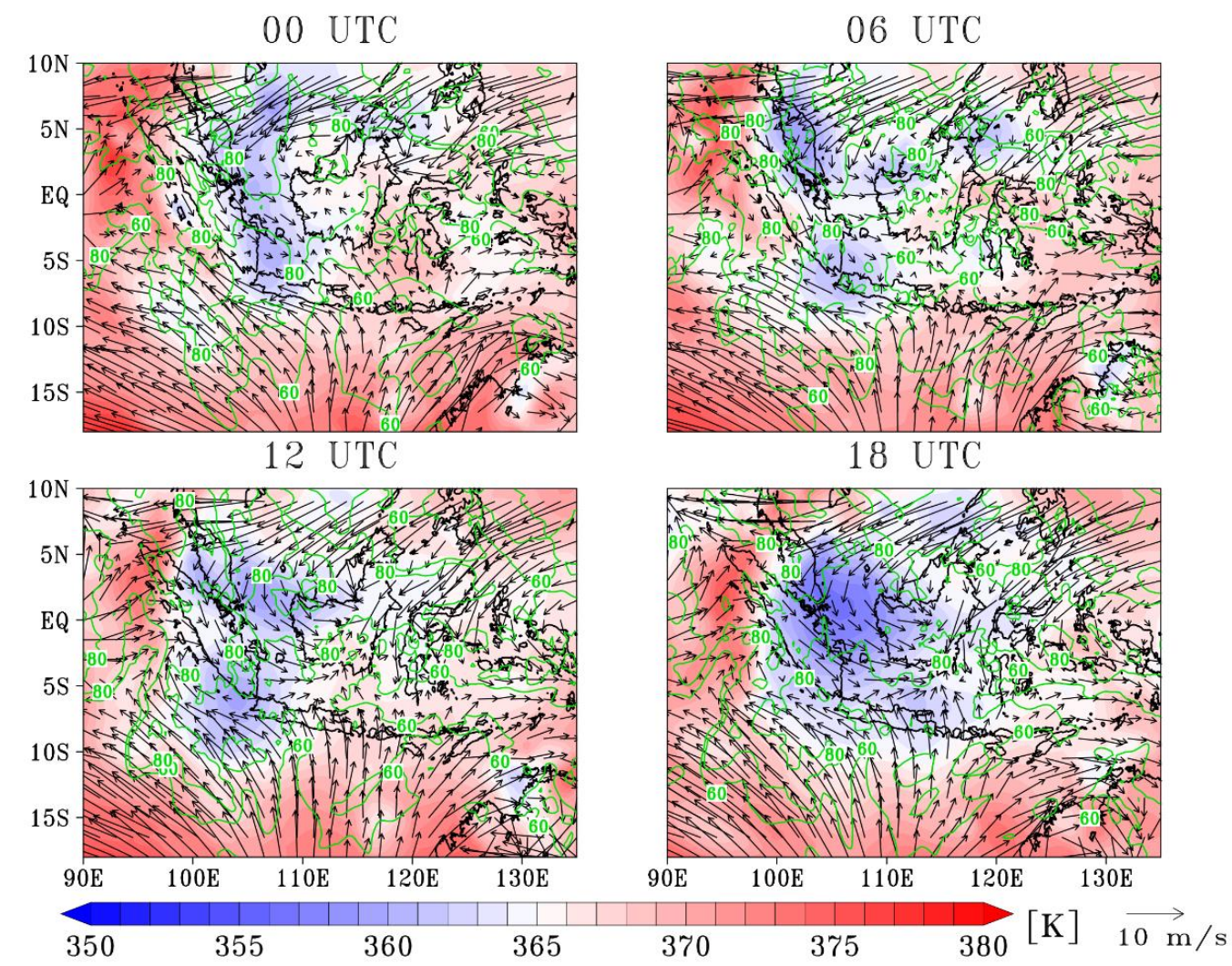

Gambar 3. Komposit peta sinoptik pada tanggal 7 Desember 2018, dimana shaded merupakan suhu potensial, vektor merupakan angin lapisan $925 \mathrm{mb}$, dan kontur berwarna hijau merupakan kelembapan relatif lapisan $700 \mathrm{mb}$

Kejadian hujan ekstrem yang terjadi pada bulan Desember bertepatan dengan sedang berlangsungnya musim dingin di Belahan Bumi Utara (Desember-Februari). Selama periode tersebut, sebagian wilayah Indonesia, khususnya bagian barat mengalami musim penghujan. Karakteristik skala sinoptik berdasarkan profil angin adalah bertiup dari arah timur utara (north easterly) di Laut China Selatan yang kemudian dibelokkan di wilayah ekuator menjadi arah baratan oleh karena topografi pulau Sumatra. Hal inilah yang menjadikan pada periode waktu ini sering disebut musim angin baratan, karena angin secara umum bertiup dari arah baratan.

Terdapat dua sistem angin yang setidaknya berpengaruh terhadap pembentukan awan penghasil hujan ekstrem yaitu yang berasal dari utara dan dari selatan. Kedua sistem angin ini kemudian bertemu tepat di sebelah utara Pulau Jawa. Aliran massa udara dari utara ini dapat memicu terbentuknya awan konvektif skala meso terutama apabila berinteraksi dengan sirkulasi angin lokal akibat topografi permukaan. Dalam kasus ini, aliran udara dari selatan yang juga cukup kuat intensitasnya menyebabkan daerah konvergensi massa udara yang selanjutnya berpotensi tinggi terbentuk awan-awan konvektif skala meso. 
Intensitas kecepatan angin pada Laut Cina Selatan cukup tinggi dengan nilai lebih dari $10 \mathrm{~m} / \mathrm{s}$. Namun, propagasi aliran massa udara tersebut membutuhkan waktu untuk sampai ke wilayah Indonesia. Hal ini dibuktikan dengan nilai kecepatan angin yang tidak terlalu kuat intensitasnya pada pukul 0000 UTC (semua waktu dalam UTC, untuk selanjutnya UTC tidak ditampilkan) $(<5 \mathrm{~m} / \mathrm{s})$ di wilayah Selat Karimata hingga Laut Jawa. Pukul 0600, kecepatan angin mulai meningkat dengan nilai sekitar $5 \mathrm{~m} / \mathrm{s}$ di wilayah Selat Karimata, meskipun belum terlalu signifikan di Laut Jawa. Intensitas kecepatan angin kemudian meningkat cukup signifikan pada pukul 1200 dan puncaknya pukul 1800 dengan nilai lebih dari $8 \mathrm{~m} / \mathrm{s}$ di wilayah Laut Jawa.

Kecepatan angin yang juga cukup kuat dari arah selatan mendukung konvergensi dan memicu awan deep convective dengan meningkatkan adveksi udara hangat di Pulau Jawa bagian selatan. Terjadinya adveksi hangat ini ditunjukkan oleh suhu potensial yang lebih tinggi dari arah selatan daripada di wilayah Pulau Jawa. Kecepatan angin yang tinggi menunjukkan adanya sistem konvektif skala meso yang cukup besar karena kecepatan angin yang kuat meningkatkan adveksi hangat ke daerah deep convective [21]. Hal ini dibuktikan dengan pertumbuhan awan yang cukup masif di Pulau Jawa bagian selatan mulai pukul 0900 (Gambar 6.a) yang kemudian semakin masif pertumbuhannya pada pukul 1800 (Gambar 6.e) seiring dengan meningkatnya angin yang berasal dari selatan disertai dengan seruakan massa udara dingin yang berasal dari utara (Gambar 3).

Aliran massa udara yang berasal dari utara bersifat dingin karena berasal dari dataran tinggi Asia yang juga sedang mengalami musim dingin. Namun, memiliki kandungan uap air yang cukup melimpah karena penjalarannya melewati perairan luas yang merupakan sumber uap air yang dihasilkan dari penguapan air laut (dibuktikan dengan nilai RH lebih dari 80\%). Hal ini semakin didukung dengan kondisi suhu muka laut yang hangat dengan anomali lebih dari $1^{\circ} \mathrm{C}$ (gambar tidak ditampilkan). Aliran massa udara ini apabila kuat intensitasnya dapat berpropagasi melewati ekuator yang kemudian disebut sebagai cross equatorial northerly surge (CENS) [11]. Wu, et al (2007) [22] menemukan bahwa fenomena trans ekuatorial ini menjadi penyebab utama terjadinya hujan ekstrem dengan durasi yang lama meskipun tanpa adanya pengaruh dari fenomena variabilitas iklim yang lain seperti ENSO, IOD, dan MJO.

\subsection{Analisis Skala Meso}

\subsubsection{Model WRF}

Luaran model WRF yang akan dianalisis adalah curah hujan dan convective available potential energy (CAPE). Curah hujan, baik secara temporal maupun spasial dianalisis terlebih dahulu untuk mengetahui performa model dalam mengestimasi curah hujan dalam satu hari. Perbandingan secara temporal di SMC ditampilkan dalam grafik pada Gambar 4.a. Metode statistik sederhana menggunakan root mean square error dan mean absolute error masing-masing menghasilkan nilai 9.94 dan 48.6. Kedua nilai tersebut menandakan bahwa model WRF belum dapat mengestimasi curah hujan sesuai dengan nilai yang sebenarnya berdasarkan skema parameterisasi yang digunakan dalam penelitian ini. Hal ini dibuktikan dengan cukup jelas bahwa nilai curah hujan yang dihasilkan dari luaran WRF sangat underestimate dengan selisih secara akumulatif sebesar $48,3 \mathrm{~mm}$. 
Sementara itu, obsevasi satelit GSMaP cukup baik dalam mengestimasi curah hujan, baik secara temporal maupun pola spasial akumulatif dalam dua puluh empat jam.
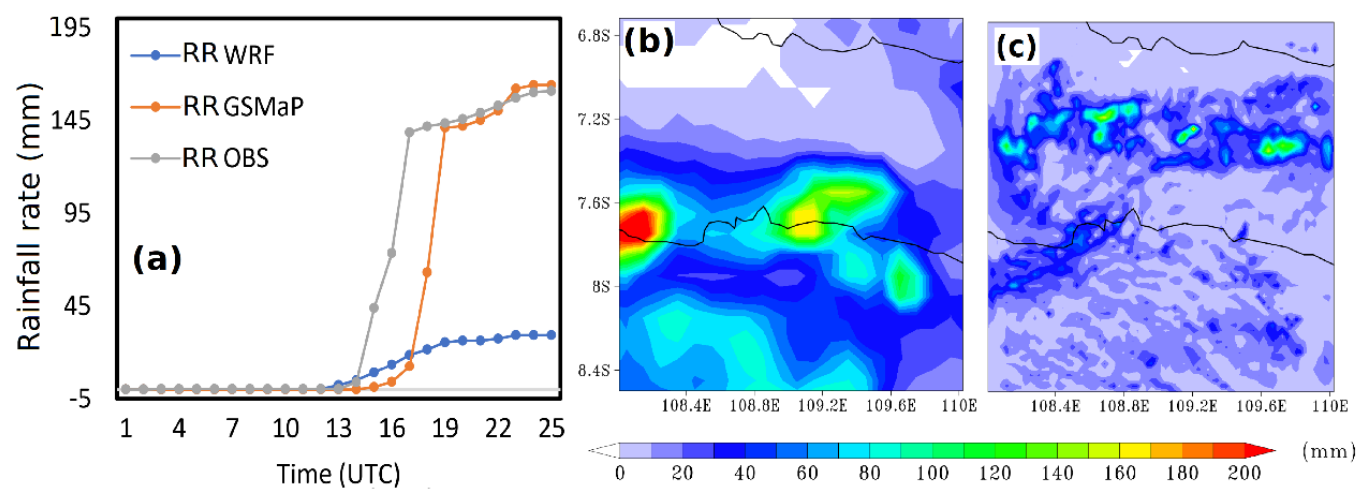

Gambar 4. (a) Perbandingan curah hujan pada SMC untuk WRF, GSMaP, dan observasi.

Perbandingan curah hujan spasial antara (b) satelit GSMaP dan (c) luaran model WRF

Nilai CAPE cukup penting untuk dianalisis karena digunakan sebagai bahan parameterisasi konvektif, dalam hal ini untuk skema KF. Nilai CAPE dibandingkan secara spasial pada pukul 1200 dengan model reanalisis ERA5 pada Gambar 5.a-b. terlihat dengan jelas bahwa terdapat perbedaan antara WRF dengan ERA5, dimana luaran model WRF lebih detail dalam membedakan nilai CAPE untuk wilayahwilayah tertentu. Selain itu, terdapat perbedaan nilai secara keseluruhan, dimana WRF mengestimasi nilai CAPE lebih dari $1500 \mathrm{~J} / \mathrm{kg}$ sedangkan ERA5 hanya sebesar $500 \mathrm{~J} / \mathrm{kg}$. Nilai CAPE yang dihitung berdasarkan observasi radiosonde di SMC tidak terlalu tinggi nilainya, yaitu hanya sebesar $435.6 \mathrm{~J} / \mathrm{kg}$. Nilai yang tidak terlalu tinggi ini kemungkinan disebabkan oleh adanya sistem awan $\mathrm{Cb}$ yang sangat masif tepat diatas titik pengamatan, sehingga radiosonde hanya mampu mengamati atmosfer sampai sekitar ketinggian $500 \mathrm{mb}$ (gambar tidak ditampilkan). Sementara itu, gerakan udara ke atas dan kebawah dapat terlihat pada Gambar 5.c. Nilai positif (negatif) menandakan adanya pergerakan udara ke atas (ke bawah) yang berkaitan dengan pertumbuhan (peluruhan) awan.
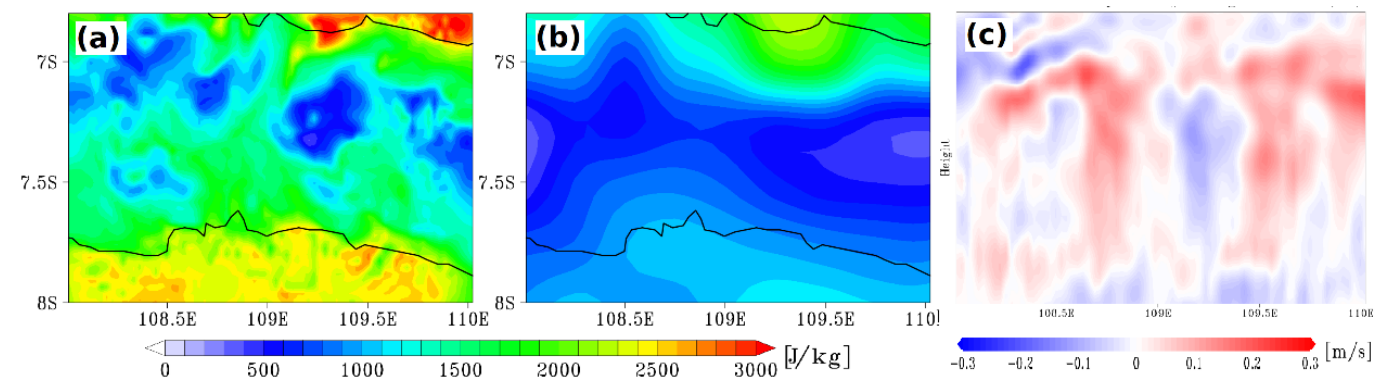

Gambar 5. CAPE yang divisualisasikan dalam bentuk peta spasial untuk (a) model WRF dan

(b) ERA5 serta (c) komponen angin vertikal (w) pada pukul 1200 UTC. Komponen angin vertikal ditampilkan dalam grafik hovmoller untuk rata-rata latitude 7.7S hingga 7S, dimana $\mathrm{x}$ axis menandakan bujur sedangkan y axis menandakan ketinggian 


\subsubsection{Citra Satelit Himawari-8}

Citra satelit himawari-8 kanal infra merah ditampilkan pada Gambar 6 untuk waktuwaktu terpilih. Pertumbuhan awan konvektif pertama kali terjadi sekitar pukul 0630, dimana awan pertama kali tumbuh di dataran tinggi (gambar tidak ditampilkan). Tumbuhnya awan disekitar dataran tinggi ini sesuai dengan pola diurnal konvektif di Pulau Jawa, dimana prosesnya dipengaruhi oleh pemanasan lokal dan perbedaan topografi wilayah [22]. Pertumbuhan awan tersebut terus berlanjut hingga memasuki fase matang sekitar pukul 0900 (Gambar 6.a). Ini merupakan awan konvektif pertama yang muncul di wilayah Cilacap. Pukul 1100, awan tersebut mulai meluruh secara keseluruhan bersamaan dengan tumbuhnya awan konvektif baru dengan jarak yang cukup jauh dengan wilayah Cilacap (ditandai dengan lingkaran pada Gambar 6.b). Awan tersebut kemudian bergerak ke barat daya menuju wilayah Cilacap. Hal ini hampir sama dengan kasus hujan sangat lebat penyebab banjir yang terjadi pada 17 November 2020, meskipun ukuran awan konvektif yang tidak semasif pada kasus ini [23].

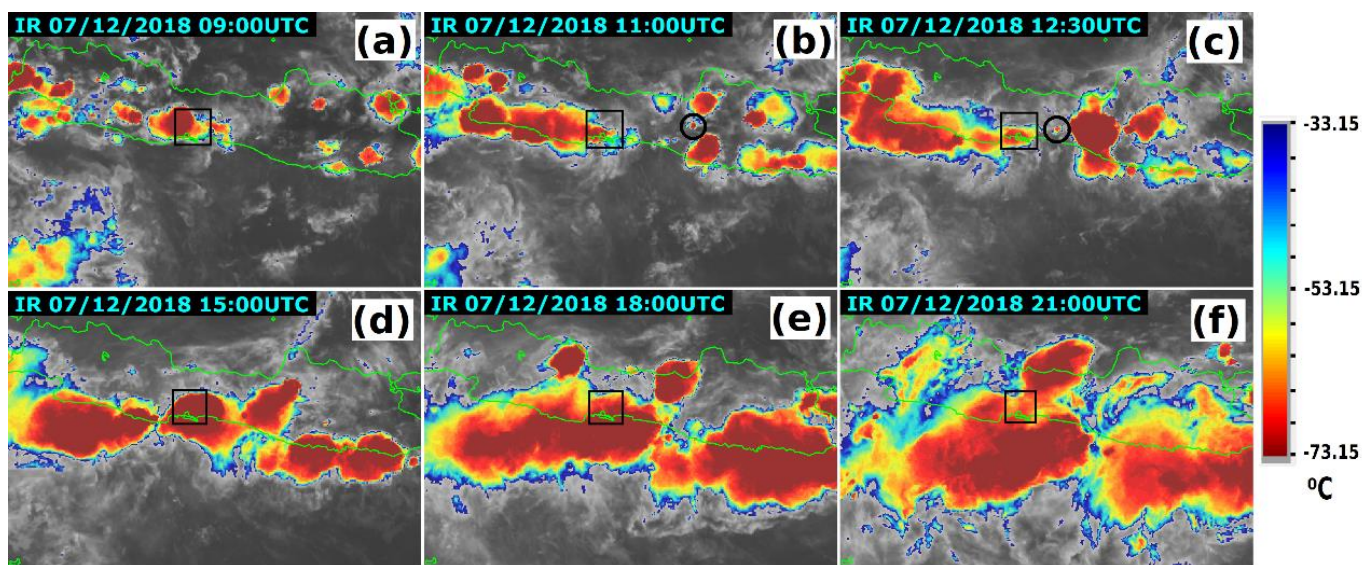

Gambar 6. Citra satelit himawari-8 kanal ir pada tanggal 7 desember 2018. Kotak berwarna hitam merupakan wilayah cilacap, sedangkan lingkaran hitam pada gambar b dan c menandakan pertumbuhan awal awan konvektif yang berbeda

Pukul 1230, terdapat pertumbuhan awan baru yang terindera oleh satelit (Gambar 6.c) bersamaan dengan fase matang untuk awan sebelumnya, keduanya berjarak cukup jauh. Pergerakan awan kedua yang menuju arah barat daya kemudian bergabung dengan awan yang ketiga. Kedua awan tersebut kemudian membentuk suatu sistem awan konvektif skala meso yang bertahan cukup lama. Pukul 1500, sistem awan tersebut telah berada tepat di wilayah Cilacap yang kemudian bertahan di wilayah tersebut hingga pukul 2100 yang mulai bergerak perlahan menuju perairan selatan jawa, namun tetap berpengaruh di wilayah Cilacap. Sistem awan konvektif skala meso ini cukup masif yang ditunjukkan dengan nilai suhu puncak awannya lebih rendah daro $-80^{\circ} \mathrm{C}$ (time series suhu puncak awan pada Gambar 7). Dengan demikian, masa hidup sistem awan konvektif yang bertahan hingga lebih dari enam jam ini jelas sangat potensial dalam menimbulkan hujan ekstrem dengan durasi yang lama. 


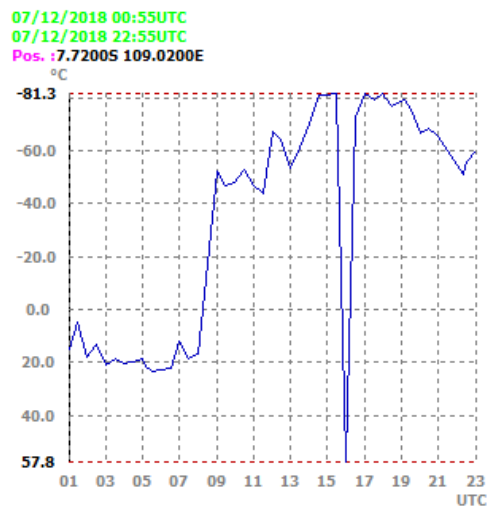

Gambar 7. Time series suhu puncak awan di titik SMC. Perlu diperhatikan pada pukul 1600 UTC terdapat data hilang sehingga nilai suhu puncak awan tidak sesuai dengan yang semestinya

\section{Kesimpulan}

Penelitian ini mengkaji dinamika atmosfer penyebab hujan ekstrem yang terjadi pada 7 Desember 2018 di Stasiun Meteorologi Cilacap dengan fokus pembahasan pada analisis skala sinoptik dan skala meso. Hal ini dilakukan karena hujan ekstrem yang terjadi dalam waktu yang lama biasanya disebabkan oleh awan-awan yang tumbuh karena sirkulasi skala yang lebih luas daripada hanya dipengaruhi oleh konveksi skala lokal. Sirkulasi atmosfer skala sinoptik menunjukkan bahwa terdapat pertemuan dua massa udara yaitu dari utara dan dari selatan yang terjadi di pulau jawa. Keduanya memiliki intensitas yang cukup kuat. Hal yang patut digarisbawahi adalah aliran massa udara dari utara ini merupakan hasil dari seruakan dingin yang berasal dari dataran tinggi Asia yang berpropagasi hingga melewati ekuator. Selain itu, kecepatan angin yang cukup kuat dari arah selatan mendukung konvergensi dan memicu awan deep convective dengan meningkatkan adveksi udara hangat di Pulau Jawa bagian selatan, khususnya dalam hal ini daerah Cilacap. Analisis skala meso dilakukan menggunakan simulasi numerik untuk mengestimasi curah hujan secara spasial serta menggunakan citra satelit Himawari8. Simulasi numerik yang dilakukan menggunakan model Weather Research and Forecasting dengan penyesuaian skema parameterisasi tertentu belum mampu mengestimasi curah hujan dengan cukup baik dengan nilai yang underestimate dibandingkan dengan data observasi. Berdasarkan citra satelit himawari-8, terpantau dengan jelas bahwa awan yang terbentuk merupakan sistem awan konvektif skala meso dengan masa hidup lebih dari enam jam. Pertumbuhan awan tersebut cukup masif yang ditandai dengan nilai suhu puncak awan lebih rendah dari $-80^{\circ} \mathrm{C}$ pada fase matang. Dengan demikian, curah hujan yang dihasilkan termasuk hujan ekstrem sehingga mengakibatkan banjir di sebagian wilayah Cilacap.

\section{Daftar Pustaka}

1. C. S. Ramage, "Role of a Tropical 'Maritime Continent' in the Atmospheric Circulation,” Mon. Weather Rev., vol. 96, no. 6, pp. 365-370, 1968, doi: https://doi.org/10.1175/15200493(1968)096\%3C0365:ROATMC\%3E2.0.CO;2. 
2. E. Mulyana, "Hubungan Antara ENSO dengan Variasi Curah Hujan di Indonesia," J. Sains Teknol. Modif. Cuaca, vol. 3, no. 1, pp. 1-4, 2002.

3. J. Mcbride, M. Haylock, and N. Nicholls, "Relationships between the Maritime Continent Heat Source and the El Niño-Southern Oscillation Phenomenon," J. Clim., vol. 16, Sep. 2003, doi: 10.1175/1520-0442(2003)016 $<2905$ :RBTMCH>2.0.CO;2.

4. C.-P. Chang, Z. Wang, J. Ju, and T. Li, "On the Relationship between Western Maritime Continent Monsoon Rainfall and ENSO during Northern Winter," J. Clim., vol. 17, pp. 665-672, Feb. 2004, doi: 10.1175/15200442(2004)017<0665:OTRBWM>2.0.CO;2.

5. Z. X. Xu, K. Takeuchi, and H. Ishidaira, "Correlation between El NiñoSouthern Oscillation (ENSO) and precipitation in South-east Asia and the Pacific region," Hydrol. Process., vol. 18, no. 1, pp. 107-123, Jan. 2004, doi: https://doi.org/10.1002/hyp.1315.

6. E. Aldrian, L. Dümenil Gates, and F. H. Widodo, "Seasonal variability of Indonesian rainfall in ECHAM4 simulations and in the reanalyses: The role of ENSO," Theor. Appl. Climatol., vol. 87, no. 1, pp. 41-59, 2007, doi: 10.1007/s00704-006-0218-8.

7. J. H. Qian, A. W. Robertson, and V. Moron, "Interactions among ENSO, the Monsoon, and Diurnal Cycle in Rainfall Variability over Java, Indonesia," J. Atmos. Sci., vol. 67, no. 11, pp. 3509-3524, 2010, doi: 10.1175/2010JAS3348.1.

8. S. Hameed, B. N. Goswami, P. Vinayachandran, and T. Yamagata, "A dipole mode in the Tropical Indian Ocean," Nature, vol. 401, pp. 360-363, Oct. 1999, doi: $10.1038 / 43854$.

9. R. Madden and P. Julian, "Description of Global-Scale Circulation Cells in the Tropics with a 40-50 Day Period," J. Atmos. Sci., vol. 29, no. 9, pp. 1109$1123,1386$.

10. A. Zakir, W. Sulistya, and M. Khotimah, Perspektif Operasional Cuaca Tropis. Jakarta: BMKG, 2010.

11. M. Hattori, S. Mori, and J. Matsumoto, "The Cross-Equatorial Northerly Surge over the Maritime Continent and Its Relationship to Precipitation Patterns," J. Meteorol. Soc. Japan. Ser. II, vol. 89A, pp. 27-47, 2011, doi: 10.2151/jmsj.2011-A02.

12. S. Prasetyo, U. Hidayat, Y. D. Haryanto, and N. F. Riama, "Variasi dan Trend Suhu Udara Permukaan di Pulau Jawa,” J. Geogr. Media Media Inf. Pengemb. dan Profesi Kegeografian, vol. 18, no. 1, pp. 60-68, 2021, doi: 10.15294/jg.v18i1.27622.

13. M. J. Manton et al., "Trends in extreme daily rainfall and temperature in Southeast Asia and the South Pacific: 1961-1998," Int. J. Climatol., vol. 21, no. 3, pp. 269-284, Mar. 2001, doi: https://doi.org/10.1002/joc.610.

14. S. Siswanto, G. J. van Oldenborgh, G. van der Schrier, R. Jilderda, and B. van den Hurk, "Temperature, extreme precipitation, and diurnal rainfall changes in the urbanized Jakarta city during the past 130 years," Int. J. Climatol., vol. 36, no. 9, pp. 3207-3225, 2016, doi: 10.1002/joc.4548.

15. E. Aldrian, "Decreasing trends in annual rainfalls over Indonesia: A threat for the national water resource?," J. Meteorol. dan Geofi sika, vol. 7, pp. 40-49, Apr. 2007. 
16. H. Hersbach et al., "The ERA5 global reanalysis," Q. J. R. Meteorol. Soc., vol. 146, no. 730, pp. 1999-2049, Jul. 2020, doi: https://doi.org/10.1002/qj.3803.

17. K. Bessho et al., "An introduction to Himawari-8/9 - Japan's new-generation geostationary meteorological satellites," J. Meteorol. Soc. Japan, vol. 94, no. 2, pp. 151-183, 2016, doi: 10.2151/jmsj.2016-009.

18. NCEP, "NCEP FNL Operational Model Global Tropospheric Analyses, continuing from July 1999." Research Data Archive at the National Center for Atmospheric Research, Computational and Information Systems Laboratory, Boulder, CO, 2000, doi: 10.5065/D6M043C6.

19. S. U. Wicaksono and A. Kurniadi "Parameterizing the Scheme of Convective Microphysics and Planetary Boundary Layer Using WRF-ARW for a Very Heavy Rain Event in Cilacap Meteorological Station (A case study on October 8th, 2016)," Indonesian State College of Meteorology Climatology and Geophysics, 2017.

20. S. Febrianto and K. Muzaki, "Banjir di 13 Desa 4 Kecamatan di Cilacap Berangsur Surut," 2018. [Online]. Available: https://www.tribunnews.com/ regional/2018/12/07/banjir-di-13-desa-4-kecamatan-di-cilacap-berangsursurut.

21. D. E. Nuryanto, H. Pawitan, R. Hidayat, and E. Aldrian, "Characteristics of two mesoscale convective systems ( MCSs ) over the Greater Jakarta : case of heavy rainfall period 15 - 18 January 2013," Geosci. Lett., pp. 1-15, 2019, doi: 10.1186/s40562-019-0131-5.

22. P. Wu et al., "The impact of trans-equatorial monsoon flow on the formation of repeated torrential rains over java Island," Sci. Online Lett. Atmos., vol. 3, no. February, pp. 93-96, 2007, doi: 10.2151/sola.2007-024.

23. S. Prasetyo, M. I. S. Maulana, and A. Zakir, "Tinjauan Meteorologis Pada Fenomena Hujan Lebat Penyebab Banjir (Studi Kasus: Cilacap, 16-17 November 2020 Dan Kendal, 19 November 2020)," J. Mater. dan Energi Indones., vol. 10, no. 9, pp. 37-48, 2020, [Online]. Available: http://jurnal.unpad.ac.id/jmei/article/view/31575. 